${ }^{I}$ Universidade do Estado do Rio de Janeiro (UERJ),

Instituto de Estudos Sociais e Políticos (IESP),

Rio de Janeiro, RJ, Brasil

jmdomingues@iesp.uerj.br

José Maurício Domingues'

\title{
WEBER, FRANKFURT, GABRIEL COHN
}

Cohn, Gabriel. (2017). Weber, Frankfurt:

teoria e pensamento social 1.

Rio de Janeiro: Azougue, 272p.

Uma obra, nas ciências sociais, nas ditas ciências humanas de modo geral, se faz tateando. Não que ao menos alguns autores não se ponham questões cujo enfrentamento por vezes atravessa sua vida toda, ao contrário. Mas, como observa Gabriel Cohn em páginas do livro a que esta resenha se dedica, eles não sabem necessariamente o que fazem, conforme mesmo a citação bíblica que o decano brasileiro da teoria sociológica mobiliza. Quer dizer, isso é o que ocorre com os autores particularmente significativos, capazes de compor obra complexa e multifacetada, na qual o que encontramos usualmente é um misto de clareza quanto a seus propósitos e certa opacidade em relação ao que efetivamente fazem - em termos de limitações e sobretudo de aberturas para problemáticas e conceitos que muitas vezes somente depois outros pesquisadores, até mesmo de gerações futuras, conseguem vislumbrar em sua potência e potencialidade.

Teço esses comentários em função da próxima publicação dos ensaios reunidos de Gabriel Cohn, em três volumes - Weber, Frankfurt. Teoria e pensamento social, em especial de seu volume I, ao qual outros dois virão juntar-se. Finalmente teremos reunida a maior parte de seus textos, dispersos em livros e revistas variados, e será possível ter uma visão de conjunto de sua obra. Isso se acrescenta à reedição recente de seu brilhante Sociologia da comunicação: teoria e ideologia (Cohn, 20I4), que ficou durante muitos anos indisponível no mercado, ao que se soma sua já mais facilmente encon- 
trável clássica leitura da metodologia e teoria weberianas, Crítica e resignação: fundamentos da sociologia de Max Weber (Cohn, 2003). Assim, será mais fácil começar a tratar exatamente das questões que coloquei no parágrafo anterior. Ou seja, poder-se-á iniciar o esforço de análise de sua obra em ambos os sentidos mencionados: quanto aos objetivos que Cohn se pôs ao longo de uma vida intelectualmente intensa que - agora pode-se ter mais clareza disso - se traduz em um conjunto articulado de ideias e textos, bem como naquele excesso, por assim dizer, que empresta a seu pensamento denso ainda outros significados que certamente comporão seu legado permanente à sociologia e à teoria crítica brasileiras mais diretamente e ao pensamento sociológico e crítico de modo geral. Seja como for, o ponto de partida para sua obra é, quase de modo explícito, uma perspectiva plebeia, se levamos a sério, como de fato devemos, sua oposição entre ela e uma outra visão, com a qual não se identifica, de estirpe aristocrática (oposição mais precisa hoje provavelmente que aquela que opõe pensamento proletário e burguês, como na versão original da teoria crítica, ainda que as pseudoaristocracias contemporâneas montem mais em cima diretamente do dinheiro e do poder político do que outrora).

$\mathrm{Na}$ introdução a esses volumes, Cohn remete à chave analítica que propus para o entendimento de sua obra - indiferença e dominação (Domingues, 20I I). Creio que o diagnóstico que propus se justifica com uma visão mais ampla de sua produção. Isso é em particular verdadeiro no que se refere a seus textos de teoria mais gerais, os quais se completam com contribuições mais diretamente vinculadas à realidade brasileira, em que algumas preocupações distintas parecem manifestar-se, ao passo que outros reafirmam suas preocupações gerais com foco nessa realidade específica. Se a questão da "civilização" contemporânea figura em sua generalidade em vários textos, com destaque para os processos de inclusão/exclusão que a caracterizam, em outros desloca-se o acento para nossa realidade, por meio de temas como o desenvolvimento e a relação entre impunidade, punição e civilidade, configurando intervenções sobre questões que afligem um país que busca o futuro sem saber muito bem em que afinal consiste sua própria modernidade, cuja face é criticamente examinada nesses ensaios. Se a barbárie não é exclusividade nossa, de modo algum e para além, obviamente, do ocidentocentrismo, hoje cada vez mais insustentável, aqui apresenta peculiaridades que possibilitam, sem falsos paradoxos, uma leitura de cunho universal. Nela poder de Estado e capitalismo predador não poderiam senão se destacar. Deve-se sublinhar que mais adiante o confronto com o pensamento social brasileiro permitirá uma visão mais ampla dessas questões em sua obra.

Vale notar que aqui temos também uma inflexão na direção de um engajamento mais direto com a tradição marxista. Ela completa o círculo de fogo de sua análise da teoria crítica frankfurtiana, sobretudo Adorno, e de 
Weber, cujas obras se situam no centro das análises de Cohn. Não que esses autores não estejam presentes aqui, muito ao contrário. São vários os textos que os focalizam, individualmente, em confronto com outros autores (por exemplo de Weber com Tocqueville), ou no que tange a temas específicos, como poder, a comunicação ou a indústria cultural, preocupações também perenes de Cohn. Mas a eles se juntam análises como sempre finas e densas de Marx e de Gramsci, a forma no primeiro, o poder e a hegemonia no segundo (em confronto, mais uma vez, com Weber).

De certa forma, temas frankfurtianos - com a questão da experiência, que Cohn retém em detrimento, explícito, da construção luckasciana da consciência revolucionária do proletariado - orientam, a meu ver de forma precisa em especial no caso em tela, aquela discussão sobre a forma. Traz-se para diante do palco o que é em grande medida uma temática fortemente kantiana, ainda que Hegel seja mobilizado de forma mais explícita ao longo do ensaio, uma vez que tempo e dialética se acham no centro também da análise. Isso se verifica, em primeiro lugar, quando a forma oferece um núcleo mediante - e "mediação" é, como não poderia deixar de ser, essencial em sua análise - o qual a experiência se organiza, definindo aquilo que absorvemos e como construímos a realidade, seletivamente ("reduzindo a complexidade", pode-se dizer com Luhmann, cuja obra fornece o foco de outro ensaio decisivo do volume, em confronto com o não menos kantiano Simmel).
Do mesmo modo, no confronto entre Weber e Gramsci, retorna ao debate o tema do poder, da legitimidade e do que o primeiro definia, em sua própria língua alemã, como Gewalt e Gewaltsamkeit, termos de difícil tradução (força, violência, poder também, ainda que com ressonâncias distintas das de Macht), dos quais uma fina e inovadora análise é proposta. Assim, indiferença e dominação, pode-se dizer, retornam e se abrem para complementos em que cintilam por exemplo a ideia de hegemonia e questões do pensamento político estratégico. De resto, essa é questão-chave da modernidade política, à qual ambos esses clássicos e o autor aqui em tela se dedicaram com afinco, buscando ademais vinculá-la à prática, sobretudo no que concerne ao intelectual comunista italiano, ainda que no final da vida a Weber importasse enormemente como essas questões se desdobravam na República de Weimar.

Outros textos completam o volume, sobre temas mais específicos. Incluem eles a identidade, a temporalidade, a música e a racionalização em Weber, a sociedade da informação (em que a questão da forma retorna, ao passo que o tempo se coloca como central também na análise da forma em Marx).

Em suma, vários são os temas, centrais e reiterados os eixos, a partir dos quais se constrói a obra de Cohn, sobretudo se damos atenção aos dois livros já citados nesta resenha, em que o desassossego com a dominação e o poder, sua seletividade e características específicas na modernidade, se mostra crucial. Creio que ele se rami- 
fica em outras preocupações mais particulares, que se apresentam nos diversos ensaios em que se retrata aqui sua trajetória. Parece-me que Cohn está ciente de ao menos grande parte das questões que busquei brevemente assinalar, embora essa seja uma leitura que se pode, entre outras, propor. Como sugeri, isso oferece apenas o início de uma análise que sua obra, agora finalmente disponível de maneira mais organizada, merece e à qual jovens cientistas sociais poderão se dedicar daqui para a frente, decerto fornecendo outras chaves de leitura e análises mais amplas. Trata-se de iniciativa editorial de grande importância para o desenvolvimento da sociologia e do pensamento crítico entre nós, tanto em termos universais quanto no que se refere a nossa autonomia intelectual.

A teoria sociológica e a teoria crítica são tão nossas quanto de norte-americanos e europeus. Cabe a nós mesmos dar-lhe produtividade em função dos temas e questões que sobressaem em nosso meio, seja em termos de suas particularidades, seja no que revela de geral, sem perder jamais sua pretensão à universalidade. Nesse sentido Cohn nos dá uma bela lição de autonomia intelectual e perspicácia teórica.

Recebida em I5/I I/20I6 Aprovada em 23/I I/20I6 


\section{REFERÊNCIAS BIBLIOGRÁFICAS}

Cohn, Gabriel. (20I4) [1973]. Sociologia da comunicação: teoria e ideologia. Petrópolis: Vozes.

Cohn, Gabriel. (2003) [1978]. Crítica e resignação: fundamentos da sociologia de Max Weber. São Paulo: Martins Fontes.

Domingues, José Maurício. (20 I I). Dominação e indiferença na teoria crítica de Gabriel Cohn. In: Teoria crítica e (semi) periferia. Belo Horizonte: Ed. UFMG.

José Maurício Domingues é doutor em sociologia pela London School of Economics and Political Science (LSE) e professor e pesquisador no IESP-UERJ. Entre seus últimos livros encontram-se Teoria crítica e (semi)periferia (20 I I), Modernidade global e civilização contemporânea: para uma renovação da teoria crítica (20I3), O Brasil entre o presente e o futuro: conjuntura interna e inserção internacional (2a. ed. revista e ampliada, 20I5). 